\title{
Bifidobacterium actinocoloniiforme sp. nov. and Bifidobacterium bohemicum sp. nov., from the bumblebee digestive tract
}

Correspondence
J. Killer
killer.jiri@seznam.cz
J. Killer, ${ }^{1}$ J. Kopečný, ${ }^{1}$ J. Mrázek, ${ }^{1}$ I. Koppová, ${ }^{1}$ J. Havlík, ${ }^{2}$ O. Benada ${ }^{3}$ and T. Kott ${ }^{4}$

\author{
${ }^{1}$ Institute of Animal Physiology and Genetics v.v.i., Academy of Sciences of the Czech Republic, \\ Vídeňská 1083, Prague 4 - Krč 142 20, Czech Republic \\ ${ }^{2}$ Czech University of Life Sciences, Department of Microbiology, Nutrition and Dietetics, \\ Kamýcká 129, Prague 6 - Suchdol 165 21, Czech Republic \\ ${ }^{3}$ Institute of Microbiology v.v.i., Academy of Sciences of the Czech Republic, Vídeňská 1083, \\ Prague 4 - Krč 142 20, Czech Republic \\ ${ }^{4}$ Institute of Animal Science, Přátelství 815, Prague - Uhříněves 104 00, Czech Republic
}

Our previous study, based primarily on PCR-denaturing gradient gel electrophoresis and 16S rRNA gene sequencing, focused on the isolation of four bifidobacterial groups from the digestive tract of three bumblebee species. In that study, we proposed that these isolated groups potentially represented novel species of the family Bifidobacteriaceae. One of the four, Bifidobacterium bombi, has been described recently. Strains representing two of the other groups have been classified as members of the genus Bifidobacterium on the basis of positive results for fructose-6-phosphate phosphoketolase activity and analysis of partial 16S rRNA and heat-shock protein 60 ( $h s p 60$ ) gene sequences. Analysis of 16S rRNA gene sequence similarities revealed that the isolates of the first group were affiliated to Bifidobacterium asteroides YIT $11866^{\top}, B$. indicum JCM $1302^{\top}$ and B. coryneforme ATCC $25911^{\top}(96.2,96.0$ and $95.9 \%$ sequence similarity, respectively), together with other bifidobacteria showing lower sequence similarity. Additional representatives of the second group were found to be affiliated to Bifidobacterium minimum YIT $4097^{\top}$ and B. coryneforme ATCC $25911^{\top}$ (96.0 and $96.3 \%$ sequence similarity) and also to other bifidobacteria with lower sequence similarity. These results indicate that the isolates of the two groups belong to novel species within the genus Bifidobacterium. This observation was further substantiated by the results of partial sequencing of hsp60. On the basis of phylogenetic and phenotypic analyses and analysis of 16S rRNA and partial $h s p 60$ gene sequences, we propose two novel species, Bifidobacterium actinocoloniiforme sp. nov. (type strain LISLUCIII-P2 ${ }^{\top}=\mathrm{DSM} 22766^{\top}=\mathrm{CCM} 7728^{\top}$ ) and

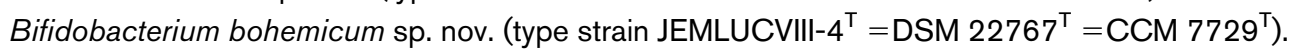

Bifidobacteria are Gram-positive, anaerobic, non-sporeforming, lactate- and acetate-producing bacteria belonging to the class Actinobacteria and, together with lactobacilli, they are the main representatives of animal and human probiotics (Reuter, 2001). At the time of writing, 28 species

Abbreviation: F6PPK, fructose-6-phosphate phosphoketolase.

The GenBank/EMBL/DDBJ accession numbers for the 16S rRNA gene sequences of strains LISLUCIII-P2 ${ }^{\top}$, LUCL-P3, JEMLUCVIII-4 ${ }^{\top}$ and JEMLUCVII-1 are FJ858731, FJ858735, FJ858736 and FJ858737; those for the partial $h s p 60$ gene sequences of the same strains are GU223108, GU238419, GU223107 and GU238418.

Three supplementary figures are available with the online version of this paper. and nine subspecies of the genus Bifidobacterium have been isolated from the gastrointestinal tracts of humans (Scardovi \& Crociani, 1974; Lauer, 1990; Hoyles et al., 2002) and other animals (Scardovi et al., 1979; Watabe et al., 1983; Biavati et al., 1991; Zhu et al., 2003), milk products (Watanabe et al., 2009) and sewage (Biavati et al., 1982). Three species of bifidobacteria were also found in honeybees (Scardovi \& Trovatelli, 1969). In addition, Mrázek et al. (2008) detected bifidobacteria through molecular techniques in other insects, including wasps (Vespula vulgaris), hornets (Vespa crabro) and cockroaches (Nauphoeta cinerea).

We have recently described the heterogeneous bifidobacterial population in the digestive tract of bumblebees 
(Killer et al., 2010), which was found to be distinct from the bifidobacterial populations in honeybees. The first named representative of the bumblebee bifidobacteria, Bifidobacterium bombi, has been described recently (Killer et al., 2009). Here, we report the results of a taxonomic study of two further representatives of the bumblebee bifidobacteria. Bacterial strains were collected from the digestive tracts of three species of bumblebee, as described previously (Killer et al., 2010). Isolates LISLUCIII$\mathrm{P} 2^{\mathrm{T}}$, LUCL-P3, JEMLUCVIII- $4^{\mathrm{T}}$ and JEMLUCVII-1 were taken as representatives of the two newly described species.

Chromosomal DNA of the selected strains was extracted using the DNeasy Blood \& Tissue kit (Qiagen). 16S rRNA gene sequences (1490 bp) were amplified by PCR with the aid of primers $\mathrm{fP} 1$ and $\mathrm{rP} 2$ and sequenced after dividing the sequences into shorter, 500 bp regions (Weisburg et al., 1991; Forster et al., 1996). The hsp60 gene has been proposed as an alternative phylogenetic marker for the family Bifidobacteriaceae (Jian et al., 2001; Huys et al., 2007). Hence, partial sequences ( 590 bp) of the $h s p 60$ gene were determined as described by Okamoto et al. (2007). Fragments were then sequenced on a 3100-Avant Genetic Analyzer with a BigDye Terminator version 3.1 cycle sequencing kit (both from Applied Biosystems). Sequence data were aligned with the CLUSTAL_X package (Thompson et al., 1997) in the BioEdit program (Hall, 1999) and the full 16S rRNA gene and partial hsp60 sequences were then compared with published sequences of related bacteria from the EMBL and GenBank nucleotide databases using the BLAST program (Maidak et al., 1994). Sequence similarities were then calculated using the PHYDIT program (Chun, 2001). The 16S rRNA gene sequences of strains LISLUCIII-P2 ${ }^{\mathrm{T}}$ and LUCL-P3 were similar to those of Bifidobacterium asteroides YIT $11866^{\mathrm{T}}, B$. indicum JCM $1302^{\mathrm{T}}$ and B. coryneforme ATCC $25911^{\mathrm{T}}$ (96.2, 96.0 and $95.9 \%$ sequence similarity, respectively). The highest $h s p 60$ gene sequence similarities of these strains were found to $B$. asteroides JCM $8230^{\mathrm{T}}(88.4 \%)$ and B. indicum JCM $1302^{\mathrm{T}}$ $(88.5 \%)$. Strains JEMLUCVIII- $4^{\mathrm{T}}$ and JEMLUCVII-1 showed the highest $16 \mathrm{~S}$ rRNA gene sequence similarity to Bifidobacterium minimum YIT $4097^{\mathrm{T}}(96 \%)$ and $B$. coryneforme ATCC $25911^{\mathrm{T}}$ (96.3\%) and other bifidobacteria. These genotypic results are in agreement with the classification of strains of different species within the genus Bifidobacterium (Stackebrandt \& Goebel, 1994; Jian et al., 2001). Affinity of strains LISLUCIII-P2 ${ }^{\mathrm{T}}$ and LUCL-P3 to honeybee bifidobacteria and strains JEMLUCVIII- $4^{\mathrm{T}}$ and JEMLUCVII-1 to $B$. minimum was substantiated through the phylogenetic tree of the family Bifidobacteriaceae (Fig. 1) based on 16S rRNA gene sequences (Simpson et al., 2003). A similar phylogenetic tree topology reconstructed using the neighbour-joining method was found based on partial $h s p 60$ gene sequences (Fig. 2). In addition, the tree topologies based on both gene sequences were confirmed using maximum-likelihood cluster analysis (Supplementary Figs S1 and S2, available in IJSEM Online).
The DNA G $+\mathrm{C}$ contents of the representative strains LISLUCIII-P $2^{\mathrm{T}}$ and JEMLUCVIII- $4^{\mathrm{T}}$ were determined using the enzymic degradation method described by Mesbah et al. (1989). The nucleotide mixture was then analysed on a Phenomenex Gemini C-18 column $(250 \times 4.6 \mathrm{~mm}$, particle size $5 \mu \mathrm{m}$ ) using a Dionex Summit System with diode array detection (Dionex Corp.). A linear gradient using eluents A (50 $\mathrm{mM} \mathrm{KH}_{2} \mathrm{PO}_{4}$, adjusted to $\mathrm{pH} 4.5$ with phosphoric acid) and $\mathrm{B}$ ( $100 \%$ acetonitrile), changing from $100 \%$ buffer $\mathrm{A}$ to $80: 20$ buffer A/buffer B over 15 min, led to separation of all nucleotides in $13 \mathrm{~min}$. The flow rate was set to $1 \mathrm{ml} \mathrm{min}^{-1}$, column temperature $32{ }^{\circ} \mathrm{C}$, injection volume $5 \mu \mathrm{l}$ and detection wavelength $250 \mathrm{~nm}$. Internal calibration references used were calf thymus, salmon sperm (both Sigma) and E. coli DNA, with DNA G + C contents of 44.0, 43.4 and $50.5 \mathrm{~mol} \%$, respectively. The DNA G $+\mathrm{C}$ contents of strains LISLUCIII-P2 $^{\mathrm{T}}$ and JEMLUCVIII-4 ${ }^{\mathrm{T}}$ were $52.7 \mathrm{~mol} \%$ (mean of five experiments, $\mathrm{SD}=0.5$ ) and $51.2 \mathrm{~mol} \%$ $(\mathrm{SD}=0.3)$, respectively. These values are lower than those of described members of the genus Bifidobacterium (53$67 \mathrm{~mol} \%$ ) (Scardovi, 1986; Okamoto et al., 2008), but higher than values for other genera within the family Bifidobacteriaceae, including Scardovia (45-55 mol\%) and Alloscardovia (47.3-48.3 mol\%) (Crociani et al., 1996; Huys et al., 2007; Downes et al., 2011). We found that B. bombi $\mathrm{BluCI} / \mathrm{TP}^{\mathrm{T}}$, the type strain of the first described Bifidobacterium species isolated from the digestive tract of bumblebees (Killer et al., 2009), also has a low DNA G+C content of $50.5 \mathrm{~mol} \%$.

Biochemical profiles for strains of both proposed species were obtained with API 50 CHL and Rapid ID 32A kits (bioMérieux) according to the manufacturer's instructions. Growth of the strains was tested in anaerobic TPY broth at $5,10,25,37$ and $47^{\circ} \mathrm{C}$ for $24-48 \mathrm{~h}$. The sensitivity of the type strains to low $\mathrm{pH}$ was determined at $37^{\circ} \mathrm{C}$ in anaerobic TPY broth at $\mathrm{pH} 3.5,4,4.5$ and 5 for $24 \mathrm{~h}$. Growth of representative strains was also tested on TPY agar at $37{ }^{\circ} \mathrm{C}$ under aerobic, microaerophilic (CampyGen generating system; Oxoid) and anaerobic conditions for 24-48 h. Table 1 shows the major phenotypic characteristics and DNA G $+C$ contents of the tested strains and related bacteria. In contrast to bifidobacteria isolated from the digestive tract of honeybees, the novel bumblebee bifidobacteria have much lower DNA G + C contents (59-60 and $50.5-52.7 \mathrm{~mol} \%$ ). All bee bifidobacteria except $B$. bombi $\mathrm{BluCI} / \mathrm{TP}^{\mathrm{T}}$ and strain JEMLUCVIII-4 ${ }^{\mathrm{T}}$ were able to grow under microaerophilic conditions. None of the strains grew under aerobic conditions. The strains were found to differ in the utilization of 14 substrates and production of alanine arylamidase.

The key enzyme of hexose catabolism in members of the family Bifidobacteriaceae is fructose-6-phosphate phosphoketolase (F6PPK) (de Vries \& Stouthamer, 1967; Jian \& Dong, 2002), through which hexoses are degraded to the end products acetic and lactic acids in a theoretical final ratio of $1.5: 1.0$. Hence, we assessed the end products of hexose catabolism for the representative strains through 


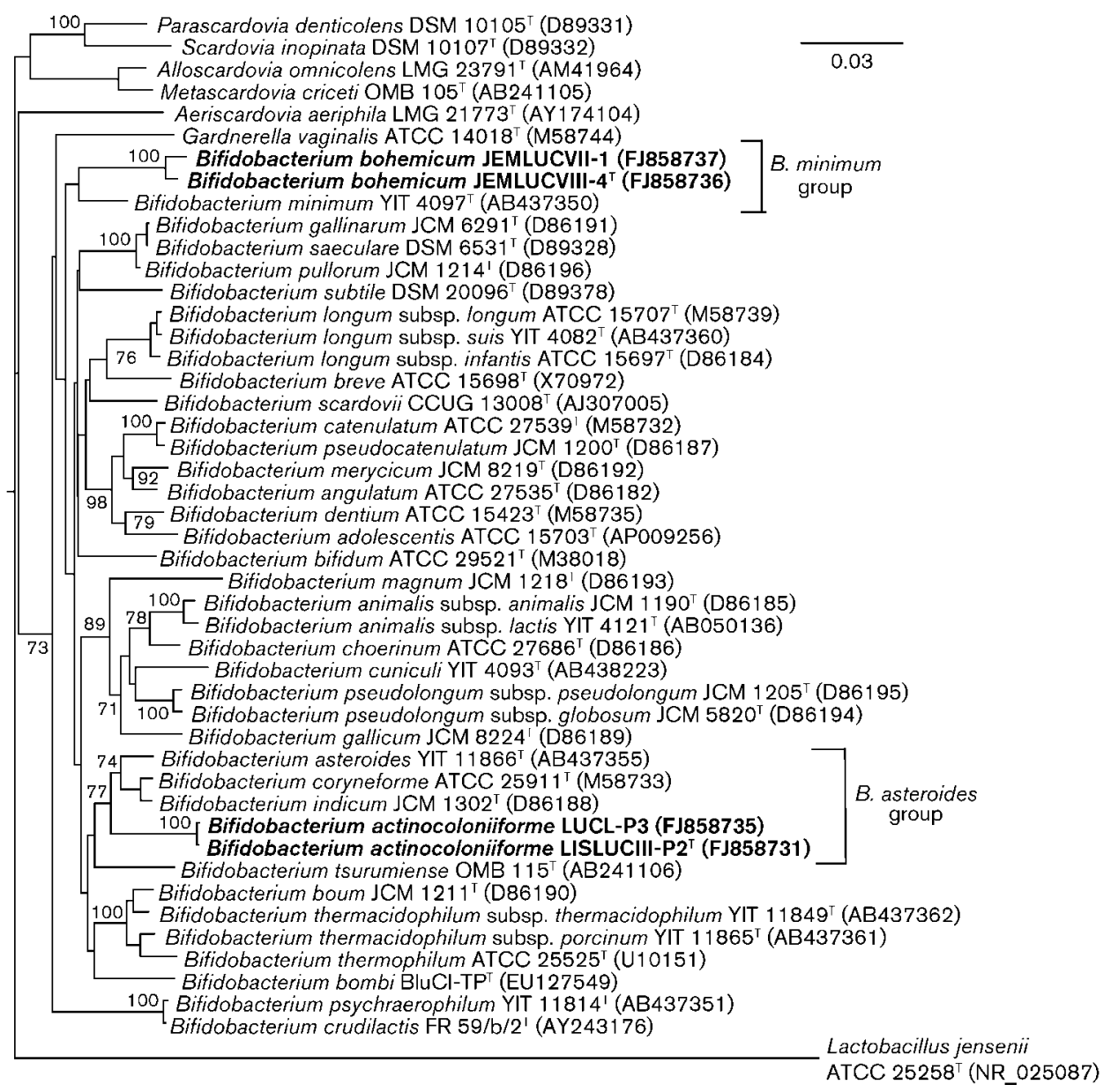

Fig. 1. Phylogenetic tree of the family Bifidobacteriaceae based on $16 \mathrm{~S}$ rRNA gene sequences (mean length $1313 \mathrm{nt}$ ) showing the position of the four novel strains from the bumblebee digestive tract. The tree was rooted with Lactobacillus jensenii ATCC $25258^{\top}$ and constructed using the neighbour-joining algorithm. Bootstrap values $>70 \%$, expressed as percentages of 1000 datasets, are given at nodes. GenBank accession numbers are given in parentheses. The phylogenetic tree was reconstructed using sequences from the type strains of bifidobacterial and scardovial species. Bar, 0.03 substitutions per nucleotide position.

capillary isotachophoresis. The strains were first cultivated in anaerobic MRS broth (Oxoid) supplemented with soybean peptone $\left(5 \mathrm{~g} \mathrm{l}^{-1}\right)$ at $37{ }^{\circ} \mathrm{C}$ for $18 \mathrm{~h}$. The cultures were then centrifuged (13000 r.p.m., $8 \mathrm{~min}$ ) and the supernatants were used for the determination of fermentation products (acetic, lactic and propionic acids) with a column-coupling instrument EA 101 (Villa Labeco Co.). Strains LISLUCIII-P2 $2^{\mathrm{T}}$ and JEMLUCVIII- $4^{\mathrm{T}}$ produced lactic and acetic acids from glucose at molar ratios of $1: 1.4$ and $1: 1.5$, respectively. Small amounts of propionic acid were also observed in both strains $\left(2.2-4.6 \mathrm{mmol} \mathrm{l}^{-1}\right)$. Some previous studies have also found propionic acid in growing cultures of bifidobacteria (Han et al., 2005).

More detailed phenotypic characterization of $B$. bombi $\mathrm{BluCI} / \mathrm{TP}^{\mathrm{T}}$ was carried out previously using cellular fatty acid profiling (Killer et al., 2009). The same method was also used for characterization and differentiation of the representative strains LISLUCIII-P2 ${ }^{\mathrm{T}}$ and JEMLUCVIII- $4^{\mathrm{T}}$.
In comparison to B. bombi $\mathrm{BluCI} / \mathrm{TP}^{\mathrm{T}}$, both strains contained much larger amounts of palmitic acid $\left(\mathrm{C}_{16: 0}\right)$ (Table 2$)$ and did not contain linoleic $\left(\mathrm{C}_{18: 2}\right)$, behenic $\left(\mathrm{C}_{22: 0}\right)$, tricosanoic $\left(\mathrm{C}_{23: 0}\right)$, lignoceric $\left(\mathrm{C}_{24: 0}\right)$ or pentadecenoic $\left(\mathrm{C}_{15: 1}\right)$ acids. Similar results for the cellular fatty acid compositions of bifidobacteria were reported by Veerkamp (1971). In comparison to the latter study, we did not detect palmitoleic $\left(\mathrm{C}_{16: 1}\right)$ acid in strain LISLUCIII-P2 ${ }^{\mathrm{T}}$ or JEMLUCVIII- $4^{\mathrm{T}}$ or B. bombi BluCI/TP ${ }^{\mathrm{T}}$.

Detailed cell morphology of strains LISLUCIII-P2 ${ }^{\mathrm{T}}$ and JEMLUCVIII- $4^{\mathrm{T}}$ was examined by scanning electron microscopy, as described previously (Killer et al., 2009). Morphological characteristics of colonies of strains related to LISLUCIII-P2 $2^{\mathrm{T}}$ growing on TPY agar under anaerobic conditions were examined using a Leica DFC480 microscope.

On the basis of genotypic, phylogenetic and phenotypic studies supported by distinctive cellular fatty acid compositions and 


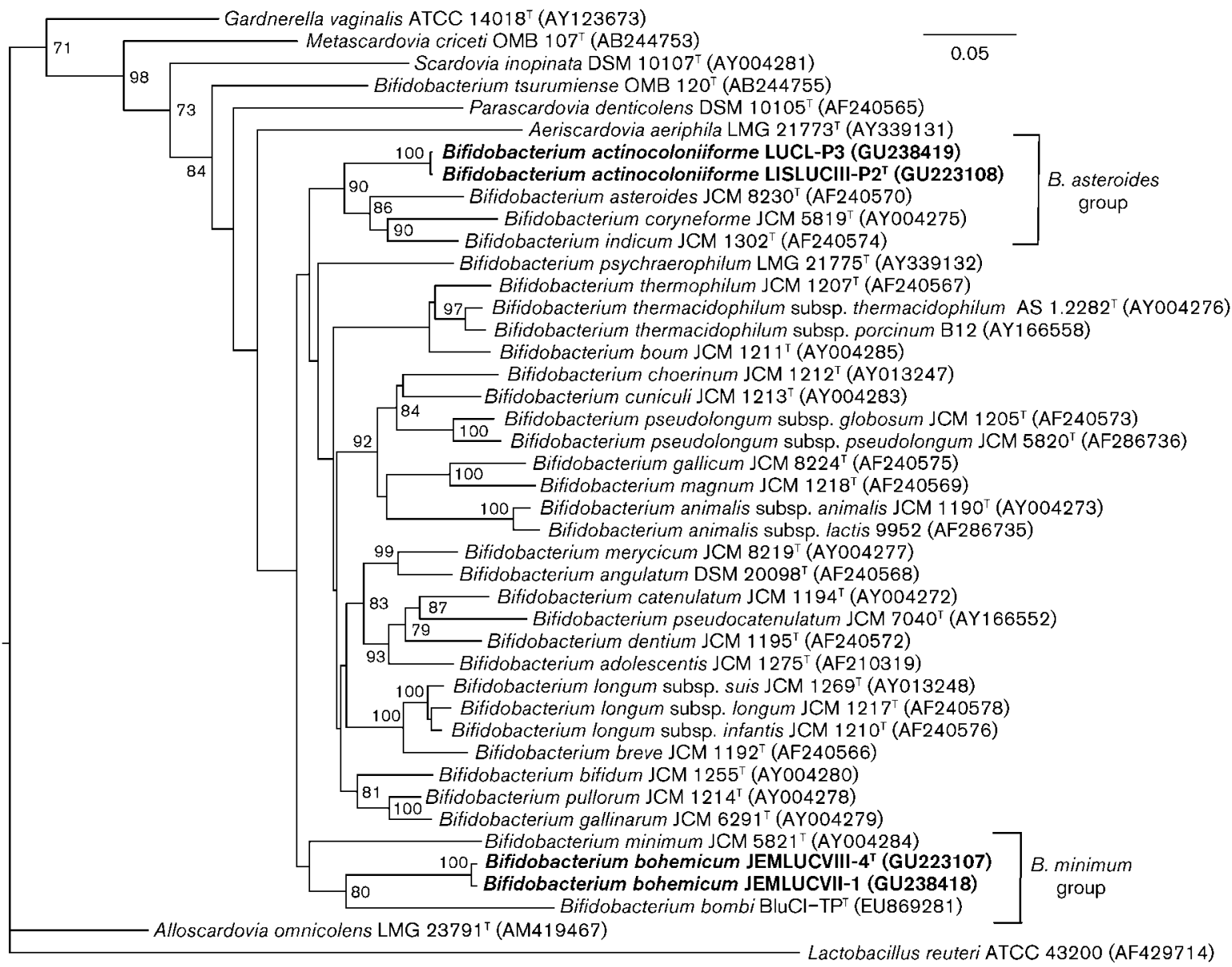

Fig. 2. Neighbour-joining phylogenetic tree, derived from analysis of partial $h s p 60$ gene sequences (552 bp), showing the position of the four novel strains from the bumblebee digestive tract. Bootstrap values $>70 \%$, expressed as percentages of 1000 datasets, are given at nodes. GenBank accession numbers are given in parentheses. Bar, 0.05 substitutions per nucleotide position.

morphological characteristics, strains LISLUCIII-P2 ${ }^{\mathrm{T}}$, LUCL-P3, JEMLUCVIII- $4^{\mathrm{T}}$ and JEMLUCVII- 1 , together with related strains, represent two novel species of the genus Bifidobacterium, for which we propose the names Bifidobacterium actinocoloniiforme sp. nov. and Bifidobacterium bohemicum sp. nov.

\section{Description of Bifidobacterium actinocoloniiforme sp. nov.}

Bifidobacterium actinocoloniiforme (ac.ti'no.co.lo'ni.i.for' me. Gr. fem. n. actis, -inos a ray; L. n. colonia a dwelling group, a colony; L. neut. adj. forme formed, shaped. N.L. neut. part. adj. actinocoloniiforme shaped like a ray-shaped colony).

Cells are Gram-type-positive, F6PPK-positive, nonmotile, non-spore-forming, irregularly shaped rods $(0.3-$ $0.6 \mu \mathrm{m}$ wide and $0.4-1.2 \mu \mathrm{m}$ long) with enlarged or tapered ends (Fig. 3a, b). They grow singly or in short chains. Colonies on TPY agar under anaerobic conditions are cream in colour, sometimes irregularly circular with entire edges and rigid cores, and reach $2.05-3.97 \mathrm{~mm}$ in diameter after 2 days of incubation. Some colonies have filamentous parts growing around the solid core (Supplementary Fig. S3) when they are incubated for $72 \mathrm{~h}$ under anaerobic conditions. Colonies are also formed under microaerophilic conditions, when they reach 1.79$2.62 \mathrm{~mm}$ in diameter after 2 days of incubation. Growth in TPY broth occurs at 25 and $37^{\circ} \mathrm{C}$, but not at $47^{\circ} \mathrm{C}$ (after 24-48 h). In TPY broth, the lowest $\mathrm{pH}$ attained is 4.5; minimum initial $\mathrm{pH}$ for growth is $\mathrm{pH}$ 5. Cells contain relatively large amounts of palmitic, oleic and stearic acids. DNA G $+\mathrm{C}$ content and biochemical parameters are shown in Table 1.

The type strain, LISLUCIII-P2 ${ }^{\mathrm{T}}\left(=\mathrm{DSM} 22766^{\mathrm{T}}=\mathrm{CCM}\right.$ $7728^{\mathrm{T}}$ ), was isolated from the digestive tract contents of a bumblebee (Bombus lucorum) sampled from Central Bohemia, Czech Republic, in 2006. 
Table 1. Differential phenotypic characteristics and DNA G+C contents of insect bifidobacteria and $B$. minimum ATCC $27538^{\top}$

Strains: 1, B. actinocoloniiforme sp. nov. LISLUCIII-P2 $2^{\mathrm{T}}$; 2, B. bohemicum sp. nov. JEMLUCVIII-4 $4^{\mathrm{T}} ; 3$, B. bombi BluCI/TP ${ }^{\mathrm{T}}$; 4 B. asteroides DSM $20089^{\mathrm{T}}$; 5, B. coryneforme DSM $20216^{\mathrm{T}} ; 6$, B. indicum DSM $20214^{\mathrm{T}} ; 7$, B. minimum ATCC $27538^{\mathrm{T}}$. Data are from this study and previous studies (Scardovi, 1986; Scardovi \& Trovatelli, 1969; Killer et al., 2009, 2010). All insect strains ferment ribose, salicin, glucose, gentiobiose and arbutin. None of the insect bifidobacteria ferment glycerol, erythritol, adonitol, methyl $\beta$-D-xylopyranoside, L-sorbose, rhamnose, dulcitol, inositol, mannitol, sorbitol, methyl $\alpha$-D-mannopyranoside, $N$-acetylglucosamine, inulin, starch, xylitol, D-lyxose, D-tagatose, D- or L-fucose, D- or L-arabitol, gluconate or 5-ketogluconate. In contrast to the insect bifidobacteria, B. minimum ATCC $27538^{\mathrm{T}}$ ferments starch and does not ferment ribose or salicin. All insect strains are positive for $\alpha$-galactosidase, $\beta$-galactosidase, $\alpha$-glucosidase, $\beta$-glucosidase, $\alpha$-arabinosidase, glycine arylamidase, arginine arylamidase, proline arylamidase, leucine arylamidase (except $B$. bombi $\mathrm{BluCI} / \mathrm{TP}^{\mathrm{T}}$ ), phenylalanine arylamidase $\left(\right.$ except $B$. bombi $\mathrm{BluCI} / \mathrm{TP} \mathrm{P}^{\mathrm{T}}$ ), tyrosine arylamidase and histidine arylamidase. All are negative for urease, indole production, nitrate reduction, arginine dihydrolase, $\beta$-galactosidase-6phosphate, $\beta$-glucuronidase, $N$-acetyl- $\beta$-glucosaminidase, $\alpha$-fucosidase, glutamic acid decarboxylase, alkaline phosphatase, pyroglutamic acid arylamidase, glutamyl glutamic acid arylamidase, catalase and oxidase. + , Positive; $(+)$, weakly positive; - , negative; ND, no data available.

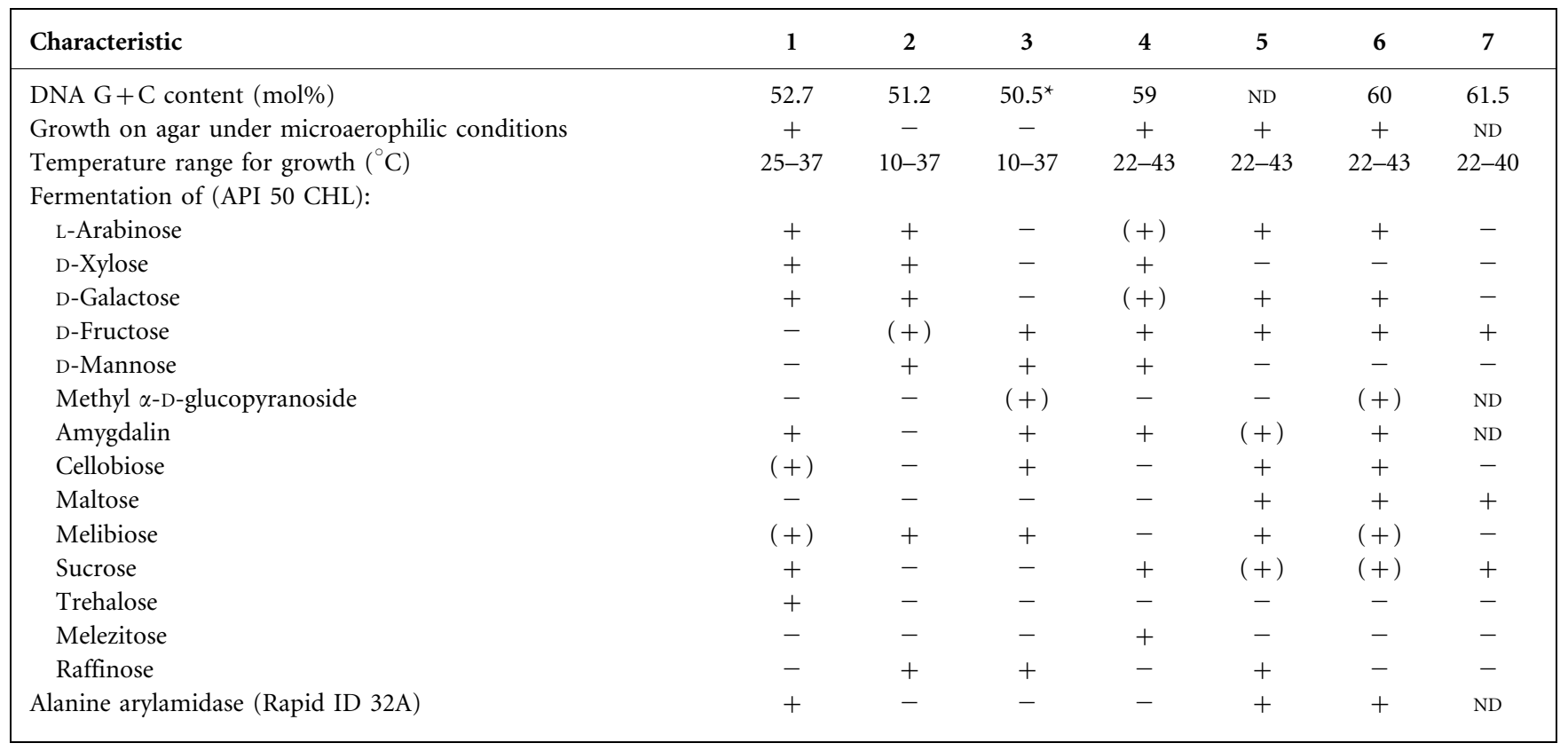

${ }^{\star}$ Revised value from this study.

Table 2. Cellular fatty acid profiles of bumblebee bifidobacteria

Strains: 1, B. actinocoloniiforme sp. nov. LISLUCIII-P2 ${ }^{\mathrm{T}} ; 2, \quad B$. bohemicum sp. nov. JEMLUCVIII-4 $4^{\mathrm{T}}$; 3, B. bombi BluCI/TP ${ }^{\mathrm{T}}$ (data from Killer et al., 2009). Relative concentrations (\%,w/v) of total fatty acids were calculated.

\begin{tabular}{|llccc|}
\hline Fatty acid & Common name & $\mathbf{1}$ & $\mathbf{2}$ & $\mathbf{3}$ \\
\hline $\mathrm{C}_{16: 0}$ & Palmitic acid & 20.17 & 15.97 & 7.14 \\
$\mathrm{C}_{18: 1}$ & Oleic acid & 9.99 & 4.69 & 7.49 \\
$\mathrm{C}_{18: 0}$ & Stearic acid & 7.05 & 6.56 & 5.91 \\
$\mathrm{C}_{20: 0}$ & Arachidic acid & 3.25 & 4.62 & 7.18 \\
$\mathrm{C}_{17: 0}$ & Margaric acid & 2.11 & 2.56 & 4.21 \\
$\mathrm{C}_{14: 0}$ & Myristic acid & 1.97 & 2.86 & $<0.01$ \\
$\mathrm{C}_{18: 2}$ & Linoleic acid & $<0.01$ & $<0.01$ & 7.34 \\
$\mathrm{C}_{22: 0}$ & Behenic acid & $<0.01$ & $<0.01$ & 5.87 \\
$\mathrm{C}_{23: 0}$ & Tricosanoic acid & $<0.01$ & $<0.01$ & 5.38 \\
$\mathrm{C}_{24: 0}$ & Lignoceric acid & $<0.01$ & $<0.01$ & 4.68 \\
$\mathrm{C}_{15: 1}$ & Pentadecenoic acid & $<0.01$ & $<0.01$ & 2.47 \\
\hline
\end{tabular}

\section{Description of Bifidobacterium bohemicum sp. nov.}

Bifidobacterium bohemicum (bo.he' mi.cum. M.L. neut. adj. bohemicum from Bohemia, referring to the Czech Republic, where the bacterium was first isolated).

Cells are Gram-type-positive, F6PPK-positive, non-motile, non-spore-forming, very irregularly shaped rods (0.2$0.4 \mu \mathrm{m}$ wide and $0.6-1.0 \mu \mathrm{m}$ long) with frequent constrictions and deformities. They are organized in chains in filament forms (Fig. 3c, d). Strictly anaerobic colonies on TPY agar under anaerobic conditions are cream in colour, circular in shape with sharp, entire edges, frequently with small irregular cores. They appear in variable shapes and sizes $(0.13-2.28 \mathrm{~mm}$ in diameter after 2 days of incubation). Optimum temperature for growth is $37^{\circ} \mathrm{C}$, with a minimum of $10{ }^{\circ} \mathrm{C}$ and a maximum of $40{ }^{\circ} \mathrm{C}$. No growth occurs at 5 or $45^{\circ} \mathrm{C}$. In TPY broth, the minimum initial $\mathrm{pH}$ for growth is $\mathrm{pH} 5$ within a period of 24-48 h (weak growth observed at $\mathrm{pH} 4.5$, and no growth observed at 

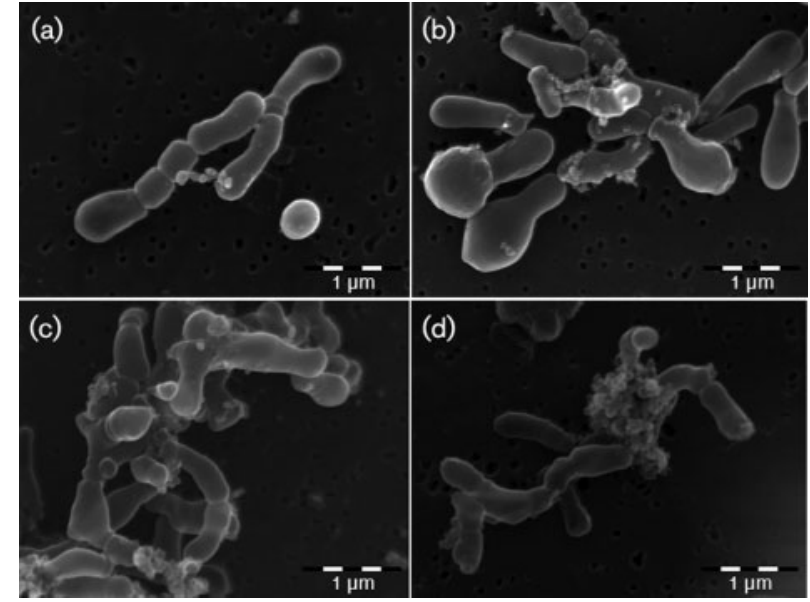

(d)

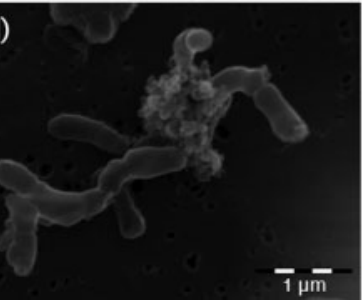

Fig. 3. Scanning electron photomicrographs of cells of Bifidobacterium actinocoloniiforme sp. nov. LISLUCIII-P2 ${ }^{\top}(\mathrm{a}, \mathrm{b})$ and Bifidobacterium bohemicum sp. nov. JEMLUCVIII- $4^{\top}$ (c, d). (a, b) Chains of curved irregular cells and clubbed cells; $(c, d)$ chains of very irregular cells and cells with occasional constrictions. Bars, $1 \mu \mathrm{m}$.

lower $\mathrm{pH}$ ). Cells contain relatively large amounts of palmitic, oleic and stearic acids. DNA G $+\mathrm{C}$ content and biochemical parameters are shown in Table 1.

The type strain, JEMLUCVIII- $4^{\mathrm{T}}\left(=\mathrm{DSM} 22767^{\mathrm{T}}=\mathrm{CCM}\right.$ $7729^{\mathrm{T}}$ ), was isolated from the digestive tract contents of a bumblebee (Bombus lucorum) sampled from South Bohemia, Czech Republic, in 2007.

\section{Acknowledgements}

This work was supported by the Grant Agency of the Czech Republic (project nos GA CR 523/08/1091 and GA CR 525/08/H060), IRP IAPG (no. AV0Z50450515) and the Ministry of Agriculture of the Czech Republic (no. MZE0002701404).

\section{References}

Biavati, B., Scardovi, V. \& Moore, W. E. C. (1982). Electrophoretic patterns of proteins in the genus Bifidobacterium and proposal of four new species. Int J Syst Bacteriol 32, 358-373.

Biavati, B., Mattarelli, P. \& Crociani, F. (1991). Bifidobacterium saeculare: a new species isolated from feces of rabbit. Syst Appl Microbiol 14, 389-392.

Chun, J. (2001). PHYDIT. Molecular sequence editor for phylogeny. Version 3.1. http://plaza.snu.ac.kr/ jchun/phydit/

Crociani, F., Biavati, B., Alessandrini, A., Chiarini, C. \& Scardovi, V. (1996). Bifidobacterium inopinatum sp. nov. and Bifidobacterium denticolens sp. nov., two new species isolated from human dental caries. Int J Syst Bacteriol 46, 564-571.

de Vries, W. \& Stouthamer, A. H. (1967). Pathway of glucose fermentation in relation to the taxonomy of bifidobacteria. J Bacteriol 93, 574-576.

Downes, J., Mantzourani, M., Beighton, D., Hooper, S., Wilson, M. J., Nicholson, A. \& Wade, W. G. (2011). Scardovia wiggsiae sp. nov.,

isolated from the human oral cavity and clinical material, and emended descriptions of the genus Scardovia and Scardovia inopinata. Int J Syst Evol Microbiol 61, 25-29.

Forster, R. J., Teather, R. M., Gong, J. \& Deng, S. J. (1996). 16S rDNA analysis of Butyrivibrio fibrisolvens: phylogenetic position and relation to butyrate-producing anaerobic bacteria from the rumen of whitetailed deer. Lett Appl Microbiol 23, 218-222.

Hall, T. A. (1999). BioEdit: a user-friendly biological sequence alignment editor and analysis program for Windows 95/98/NT. Nucleic Acids Symp Ser 41, 95-98.

Han, R., Ebert, C., Zhao, Z., Li, L., Zhang, H. \& Tian, R. (2005). Novel characteristics of Bifidobacterium bifidum in solid state fermentation system. World J Microbiol Biotechnol 21, 1245-1248.

Hoyles, L., Inganäs, E., Falsen, E., Drancourt, M., Weiss, N., McCartney, A. L. \& Collins, M. D. (2002). Bifidobacterium scardovii sp. nov., from human sources. Int J Syst Evol Microbiol 52, 995-999.

Huys, G., Vancanneyt, M., D'Haene, K., Falsen, E., Wauters, G. \& Vandamme, P. (2007). Alloscardovia omnicolens gen. nov., sp. nov., from human clinical samples. Int J Syst Evol Microbiol 57, 1442-1446.

Jian, W. \& Dong, X. (2002). Transfer of Bifidobacterium inopinatum and Bifidobacterium denticolens to Scardovia inopinata gen. nov., comb. nov., and Parascardovia denticolens gen. nov., comb. nov., respectively. Int J Syst Evol Microbiol 52, 809-812.

Jian, W., Zhu, L. \& Dong, X. (2001). New approach to phylogenetic analysis of the genus Bifidobacterium based on partial HSP60 gene sequences. Int J Syst Evol Microbiol 51, 1633-1638.

Killer, J., Kopečný, J., Mrázek, J., Rada, V., Benada, O., Koppová, I., Havlík, J. \& Straka, J. (2009). Bifidobacterium bombi sp. nov., from the bumblebee digestive tract. Int J Syst Evol Microbiol 59, 2020-2024.

Killer, J., Kopečný, J., Mrázek, J., Rada, V., Dubná, S. \& Marounek, M. (2010). Bifidobacteria in the digestive tract of bumblebees. Anaerobe 16, 165-170.

Lauer, E. (1990). Bifidobacterium gallicum sp. nov. isolated from human feces. Int J Syst Bacteriol 40, 100-102.

Maidak, B. L., Larsen, N., McCaughey, M. J., Overbeek, R., Olsen, G. J., Fogel, K., Blandy, J. \& Woese, C. R. (1994). The Ribosomal Database Project. Nucleic Acids Res 22, 3485-3487.

Mesbah, M., Premachandran, U. \& Whitman, W. B. (1989). Precise measurement of the $\mathrm{G}+\mathrm{C}$ content of deoxyribonucleic acid by high performance liquid chromatography. Int J Syst Bacteriol 39, 159-167. Mrázek, J., Štrosová, L., Fliegerová, K., Kott, T. \& Kopečný, J. (2008). Diversity of insect intestinal microflora. Folia Microbiol (Praha) 53, 229-233.

Okamoto, M., Benno, Y., Leung, K. P. \& Maeda, N. (2007). Metascardovia criceti gen. nov., sp. nov., from hamster dental plaque. Microbiol Immunol 51, 747-754.

Okamoto, M., Benno, Y., Leung, K. P. \& Maeda, N. (2008). Bifidobacterium tsurumiense sp. nov., from hamster dental plaque. Int J Syst Evol Microbiol 58, 144-148.

Reuter, G. (2001). The Lactobacillus and Bifidobacterium microflora of the human intestine: composition and succession. Curr Issues Intest Microbiol 2, 43-53.

Scardovi, V. (1986). Genus Bifidobacterium. In Bergey's Manual of Systematic Bacteriology, vol. 2, pp. 1418-1434. Edited by P. H. A. Sneath, N. S. Mair, M. E. Sharpe \& J. G. Holt. Baltimore: Williams \& Wilkins.

Scardovi, V. \& Crociani, F. (1974). Bifidobacterium catenulatum, Bifidobacterium dentium, and Bifidobacterium angulatum: three new species and their deoxyribonucleic acid homology relationships. Int $J$ Syst Bacteriol 24, 6-20.

Scardovi, V. \& Trovatelli, L. D. (1969). New species of bifidobacteria from Apis mellifica L. and Apis indica F. A contribution to the 
taxonomy and biochemistry of the genus Bifidobacterium. Zentralbl Bakteriol Parasitenkd Infektionskr Hyg Abt II 123, 64-88.

Scardovi, V., Trovatelli, L. D., Biavati, B. \& Zani, G. (1979). Bifidobacterium cuniculi, Bifidobacterium choerinum, Bifidobacterium boum, and Bifidobacterium pseudocatenulatum: four new species and their deoxyribonucleic acid homology relationships. Int J Syst Bacteriol 29, 291-311.

Simpson, P. J., Stanton, C., Fitzgerald, G. F. \& Ross, R. P. (2003). Genomic diversity and relatedness of bifidobacteria isolated from a porcine cecum. J Bacteriol 185, 2571-2581.

Stackebrandt, E. \& Goebel, B. M. (1994). A place for DNA-DNA reassociation and $16 \mathrm{~S}$ rRNA sequence analysis in the present species definition in bacteriology. Int J Syst Bacteriol 44, 846-849.

Thompson, J. D., Gibson, T. J., Plewniak, F., Jeanmougin, F. \& Higgins, D. G. (1997). The CLUSTAL_X windows interface: flexible strategies for multiple sequence alignment aided by quality analysis tools. Nucleic Acids Res 25, 4876-4882.
Veerkamp, J. H. (1971). Fatty acid composition of Bifidobacterium and Lactobacillus strains. J Bacteriol 108, 861-867.

Watabe, J., Benno, Y. \& Mitsuoka, T. (1983). Bifidobacterium gallinarum sp. nov.: a new species isolated from the ceca of chickens. Int J Syst Bacteriol 33, 127-132.

Watanabe, K., Makino, H., Sasamoto, M., Kudo, Y., Fujimoto, J. \& Demberel, S. (2009). Bifidobacterium mongoliense sp. nov., from airag, a traditional fermented mare's milk product from Mongolia. Int J Syst Evol Microbiol 59, 1535-1540.

Weisburg, W. G., Barns, S. M., Pelletier, D. A. \& Lane, D. J. (1991). $16 \mathrm{~S}$ ribosomal DNA amplification for phylogenetic study. J Bacteriol 173, 697-703.

Zhu, L., Li, W. \& Dong, X. (2003). Species identification of genus Bifidobacterium based on partial HSP60 gene sequences and proposal of Bifidobacterium thermacidophilum subsp. porcinum subsp. nov. Int J Syst Evol Microbiol 53, 1619-1623. 